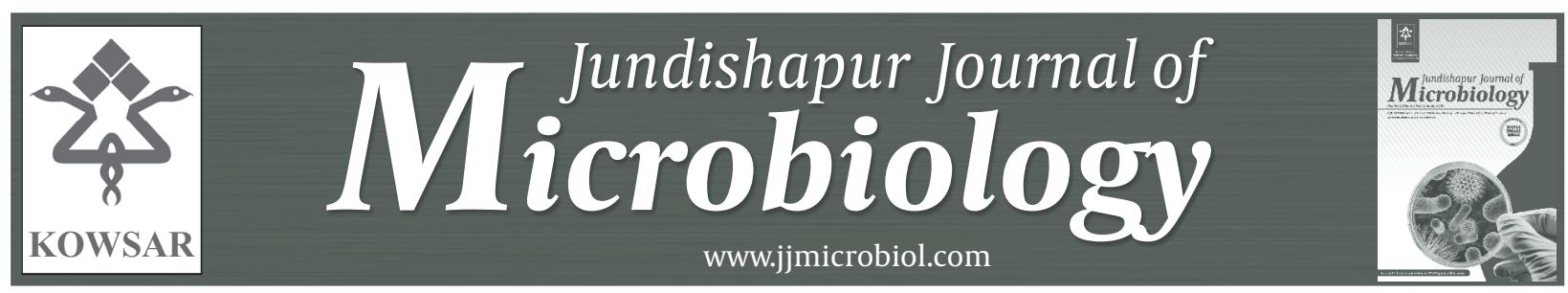

\title{
Antimicrobial Activity of Heterotrophic Bacterial Strains of Marine Origin
}

\author{
Beleneva Irina Alekseevna ${ }^{1}$, Kukhlevsky Andrey Danilovich ${ }^{2,3}$, Kharchenko Ulyana \\ Valerievna $^{3^{*}}$ \\ ${ }^{1}$ A.V. Zhirmunsky Institute of Marine Biology, Far East Branch, Russian Academy of Sciences, Vladivostok, Russia \\ ${ }^{2}$ Far-Eastern Federal University, Vladivostok, Russia \\ ${ }^{3}$ Institute of Chemistry Far Eastern Branch of Russian Academy of Science, Vladivostok, Russia \\ * Corresponding author: Kharchenko Ulyana Valerievna , Institute of Chemistry Far Eastern Branch of Russian Academy of Science, pr.100-letiya Vladivo- \\ stoka, 690022, Vladivostok, Russia.Tel.: +42-32313301, E-mail: kcharchenko@ich.dvo.ru
}

\section{A B S T R A C T}

Background: Bacterium-bacterium antagonistic interactions could be important in the ecology of marine bacteria. Antimicrobial properties of microorganisms are exploited in various fields of human activities.

Objectives: Antagonism of heterotrophic bacteria from different marine environments of tropical and temperate zones was examined. Materials and Methods: Bacteria were isolated from biofilm samples, tissues of hydrobionts and sea water. Isolates were characterized by phenotypic and 16S rRNA phylogenetic analyses. Agar diffusion assay was applied to investigate inhibitory interactions. 5 type strains and 21 strains of marine origin were used as test cultures.

Results: $68.97 \%$ of isolates from temperate zone and $56.76 \%$ of tropical zone showed antimicrobial activity. The most active strains belonged to genera Pseudomonas and Pseudoalteromonas.

Conclusions: Bacterial interspecies growth inhibition is widely distributed in marine environments. Marine bacteria, especially Vibrio spp., may be good probiotics which are active against pathogenic bacteria.

Keywords: Aquatic Organisms; Antimicrobial Activity; Probiotics

Copyright ( 2013, Kowsar Corp.; Published by Kowsar Corp.

Article type: Research Article; Received: 05 Apr 2012, Revised: 22 May 2012, Accepted: 07 Jun 2012; DOI: 10.5812/jjm.5039

Implication for health policy/practice/research/medical education:

Our results demonstrated selective activity of isolates from different climatic zones against human pathogens. It may help in search strategy for new probiotics of marine bacterial origin.

-Please cite this paper as:

Beleneva Irina A, Kukhlevsky Andrey D, Kharchenko Ulyana V. Antimicrobial Activity of Heterotrophic Bacterial Strains of Marine Origin. Jundishapur J Microbiol.2013;6(2): 166-175. DOI: 10.5812/jjm.5039

(C) 2013 Ahvaz Jundishapur University of Medical Sciences; Published by Kowsar Corp.

This is an Open Access article distributed under the terms of the Creative Commons Attribution License (http://creativecommons.org/licenses/by/3.0), which permits unrestricted use, distribution, and reproduction in any medium, provided the original work is properly cited. 


\section{Background}

Bacterium-bacterium interactions, diverse in form and content are widely seen in water column with different microparticles. Over one half of marine bacteria examined so far have displayed antagonistic activity towards other pelagic bacteria. Antimicrobial interactions influence, first, the structure of the microbial community and second, the functioning of microbial cenoses (1). Microbial antagonism results from the effects of antibiotic substances inhibiting the growth of microorganisms or killing them. Bacterial production of secondary metabolites, in particular growth inhibitors, is one of the adaptation mechanisms, which gives advantage in competition for available nutrients and living space.

Searching for previously unknown microbial strains is an effective approach to obtain new biologically active substances. Marine bacteria are producers of unique substances which have never been found in terrestrial organisms $(2,3)$. Secondary metabolites of microbial origin are widely used in various fields of human activities, such as medicine, agriculture, pharmaceuticals, food processing, chemical industries and many others. In addition to production of antibiotics and lytic enzymes (4), the antimicrobial properties of microorganisms are used to work out biofilms with anticorrosion and antifouling properties $(5,6)$ and to enhance crop protection against phytopathogenic bacteria (7) and fungi (8).

In aquaculture, the usage of live cultures of antagonistic bacteria as probiotics is developing to prevent outbreaks of diseases in aquatic organisms $(9,10)$. The interest to biological control in the past two decades has increased dramatically due to expanding opportunities for synthesis of biological products and highly competitive chemical preparations which could often inflict enormous damage to the environment (11).

\section{Objectives}

The aim of our study was to investigate the peculiarities of bacterium-bacterium antagonistic interactions among heterotrophic bacteria of marine origin in tropical and temperate zones. This would be helpful to clarify some problems concerning the role of biosynthesis of antimicrobial substances in natural bacterial communities and could also be helpful to develop a strategy of search for new physiologically active substances of bacterial origin.

\section{Materials and Methods}

\subsection{Sampling}

Heterotrophic bacteria were isolated from different marine objects in Nha Trang Bay, South China Sea in June-July 2008 and January 2009; in the pelagic part of the East China Sea in April 2010; and in Peter the Great Bay, Sea of Japan, in August 2008, 2009 and 2010 in Nha Trang Bay. Invertebrates and algae were collected by scuba divers from depths of three to 23 meters. Microflora samples of the fouling of copper-containing and aluminum plates were selected on a test bench of Marine Corrosion Station, Primorsky Branch of Russian-Vietnamese Tropical Center, Nha Trang (Vietnam). Water samples were taken directly at exposure points of metal plates. The samples of algae included the green alga Caulerpa lentillifera and brown algae Padina spp., Turbullaria spp. and Sargassum spp. The samples of animals included the ascidian Didemnum molle, bivalves Pinctada margaritifera and Crassostrea gigas and unidentified species of sponges (three samples).

\subsubsection{Open Part of the East China Sea}

Water samples were collected using a Niskin bottle at the points with coordinates $29^{\circ} 40,647 \mathrm{C}^{\mathrm{N}} \mathrm{N}, 124^{\circ} 27,909^{\prime} \mathrm{E}$ and $26^{\circ} 46,326^{\prime} \mathrm{N}, 121^{\circ} 41,916$ 'E.

\subsubsection{Peter the Great Bay}

The samples of algae, animals and water were collected by scuba divers in Avangard Bight of Peter the Great Bay. The examined animals included bivalves Crenomytilus grayanus, Modiolus dificillus and C. gigas; echinoderms, sea urchins Strongylocentrotus nudus and S. intermedius; starfishes Patiria pectinifera and Asterias amurensis, and sea cucumber Apostichopus japonicus and the ascidian Halocynthia aurantium. The seaweed Laminaria japonica was examined from the plants. As test cultures the following type strains were applied: Escherichia coli ATCC 15034, Bacillus subtilis BKM B501, Candida albicans KMM 455, Pseudomonas aeruginosa KMM 433 and Staphylococcus aureus ATCC 21027.

\subsection{Isolation of Bacteria in Pure Cultures and Phe-} notypic Characterization of the Isolates

Isolation of bacteria from hydrobionts and seawater and preservation of bacterial strains were conducted as described elsewhere (12). Bacteria were isolated from internal tissues of ascidians and sponges, coelomic fluid and digestive tract of sea urchins, bivalves and starfishes and digestive tract of holothurians. Biofilm samples (8 $\mathrm{cm} 2$ in area) were scrapped off from the surface of each metal plate using a stencil and a sterile tool and then carefully taken with a sterile absorbent cotton stick. The stick with the microbial mass was placed into a test tube containing $2 \mathrm{ml}$ of sterile seawater.

Serial dilutions of homogenates, biofilm suspensions and water samples $(0.1 \mathrm{ml})$ were plated on solid Youschimizu-Kimura medium (13) with the following composition: peptone (5.0 g), yeast extract (2.0 g), glucose (1.0 g), K2HPO4 (0.2 g), MgSO4•7H2O (0.1 g), agar (12.0 g), distilled water $(500 \mathrm{ml})$, and seawater $(500 \mathrm{ml})$; the $\mathrm{pH}$ of the medium equaled 7.8 to 8.0. Cetrimide agar (Serva) supplemented with glycerol in proportion of $10 \mathrm{~g} / \mathrm{l}$ was used to isolate bacteria of the genus Pseudomonas. The plates 
were incubated for three to ten days at $28{ }^{\circ} \mathrm{C}$ for tropical isolates and at $23^{\circ} \mathrm{C}$ for isolates from temperate zone.E. coli, C. albicans, S. aureus, P. aeruginosa and B. subtilis were cultured on tryptic soya agar (TSA, Difco).

Motility and cell morphology were observed by the hanging-drop method. Gram-reaction, oxidase and catalase activities, presence of nitrate reductase, sodium ion requirements and tolerance to different $\mathrm{NaCl}$ concentrations $(0-12 \% \mathrm{NaCl})$, growth at different temperatures $\left(4-42{ }^{\circ} \mathrm{C}\right)$, acid production from sugars, production of lysine and ornithine decarboxylases and arginine dehydrolase and gelatinase, DNA base composition and resistance to antibiotics were tested as described elsewhere (14). The following antibiotics were used for tests: ampicillin (Amp), erythromycin (Ery), gentamicin (Gen), lincomycin (Lin), rifampicin (Rif), oleandomycin (Ol), polymyxin B (Pol) and vibriostatic agent 0-129 (2,4-diamino-6,7-di-isopropylpteridine) with Oxoid disks. Additional biochemical tests with API-20NE and API-20E test kits (bioMérieux) were performed as described by the manufacturers, except that strains were suspended in $3 \% \mathrm{NaCl}$.

\subsection{S rRNA Gene Sequence Analysis of Bacterial Isolates}

Total DNA was isolated using the standard technique (15). A fragment of $16 \mathrm{~S}$ rRNA gene sequence was amplified in $25 \mu \mathrm{l}$ of reaction mixture comprising $2.5 \mu \mathrm{l}$ of $10 \times \mathrm{PCR}$ buffer, $2 \mu \mathrm{l}$ of $10 \mathrm{mM}$ dNTP mixture (2.5 mM each), $2.5 \mu \mathrm{l}$ of each primer $(2.5 \mu \mathrm{M}), 10 \mathrm{ng}$ of DNA and 1 unit of Taq DNA polymerase (Fermentas). Primers amplification were performed according to Lane (16). The PCR amplification (GeneAmp PCR System 9700, Applied Biosystems) was performed using the following scheme: an initialization hold at $95^{\circ} \mathrm{C}$ for three minutes, 35 cycles each comprising 30 seconds at $94{ }^{\circ} \mathrm{C}$, one minute at $56^{\circ} \mathrm{C}$ and 1.5 minutes at $72{ }^{\circ} \mathrm{C}$ and the final hold at $72{ }^{\circ} \mathrm{C}$ for five minutes.

The purity and size of products were estimated in $1 \%$ agarose gel. The purified amplification products were applied as a matrix for sequencing, which was performed with a BigDye Terminator v3.1 Cycle Sequencing Kit (Applied Biosystems). The purified products of sequencing were subjected to electrophoresis with an ABI Prism 3130 genetic analyzer, on a $50 \mathrm{~cm}$ capillary cartridge. The obtained direct and inverse sequences for each tested species were aligned using SeqScape v2.6 (Applied Biosystems) software. The obtained fragments of 16S rRNA gene sequences were deposited in NCBI/GenBank (GenBank accession numbers. GU579451, GU579452, GU726840GU726880, JN679843-JN679865). Phylogenetic trees were developed with the Neighbor-Joining Method (NJ) (17), using Kimura's two-parametric model of nucleotide substitutions (K2P) (18) and MEGA 5 software (19). Cluster stability was estimated using bootstrap analysis (1000 iterations) (20).

\subsection{Screening of Isolates for Inhibitory Interactions}

Antimicrobial activity was tested in strains isolated in Vietnam from the surface of metal plates fouling and seawater and in Russian isolates associated either with different hydrobionts or with free-living in seawater. As test cultures strains were used isolates in tropical and temperate zones from seawater and different hydrobionts and five type strains belonging to Gram-positive bacteria, Gram-negative bacteria and yeasts. Antimicrobial activity of the isolates was assayed with a slightly modified method of Long and Azam (1). A lawn of a target isolate was prepared by mixing $25 \mathrm{ml}$ of molten $\left(44^{\circ} \mathrm{C}\right), 0.6 \% \mathrm{Ma}$ rine agar with $0.5 \mathrm{ml}$ of isolate suspension. The suspension was prepared by dilution of an MA-grown daily culture in physiological solution down to concentration of 109 cells/ml, according to the McFarland Turbidity Standard. From 12 to 16 strains of potential growth inhibitors were spotted on the lawn. The plates were incubated face up for six days at $28^{\circ} \mathrm{C}$ for tropical isolates and at $23^{\circ} \mathrm{C}$ for temperate zone and examined daily for zones of inhibition. Potential producers were considered positive, if the diameter of the inhibition zone was at least $4 \mathrm{~mm}$ greater than that of the colony formed by the potential producer.

\section{Results}

\subsection{Identification of Bacteria}

Among 66 strains analyzed for antimicrobial activity, 61 strains were identified using results of $16 \mathrm{~S}$ rRNA gene sequencing ( Figure ).

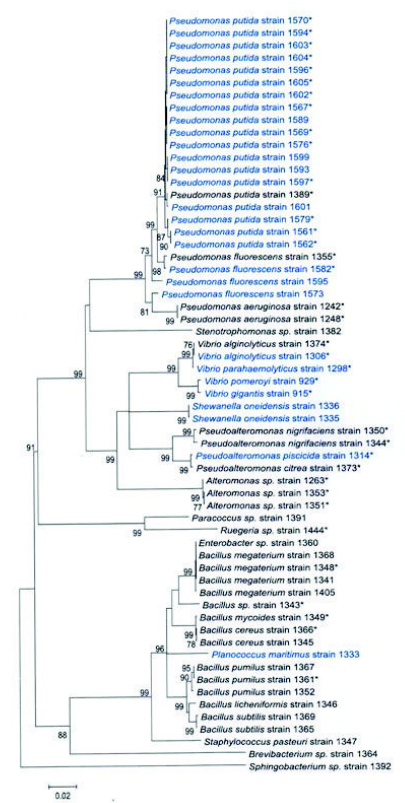

Figure. Strains Isolated from Peter the Great Bay, Sea of Japan, Russia and Nha Trang Bay, South China Sea, Vietnam Are Shown in Blue and Black, Respectively. 
The strains used as test cultures and five antagonistic strains were identified by phenotypic characteristics. The obtained data was compared with available literature to corroborate the identification of some bacterial strains. To specify the taxonomic position of some strains, antibiotics sensitivity test was applied. For example, the strain 1541 Pseudoalteromonas sp, tested for antimicrobial activity, showed oxidative metabolism pattern, possessed cytochrome oxidase, demonstrated low G/C DNA molar percentage ratio (39.5\%) and had dark brown pigment which diffused into the medium; it hydrolyzed agar and did not possess nitrate reductase. It was sensitive to rifampicin, ampicillin, erythromycin, gentamicin and polymyxin, but resistant to lincomycin and oleandomycin.

Proceeding from phylogenetic and phenotypic analysis the strains examined for antimicrobial activity were divided into five different phylogenetic groups as follow: $\gamma$ Proteobacteria (66.7\%), Firmicutes (27.3\%), $\alpha$-Proteobacteria (3\%), Actinobacteria (1.5\%), and Bacteroidetes (1.5\%). Most of $\gamma$-Proteobacteria belonged to genera Pseudomonas and Pseudoalteromonas; bacteria of genera Vibrio, Shewanella,
Alteromonas, Enterobacter, and Stenotrophomonas were registered as minor groups ( Table 1 ). Firmicutes mostly constituted of species of the genus Bacillus and also included significantly fewer members of genera Staphylococcus and Planococcus.

The group of $\alpha$-Proteobacteria included genera Ruegeria and Paracoccus; while phyla Bacteroidetes and Actinobacteria included one registered member each, namely the genera Sphingobacterium and Brevibacterium, respectively. Most Russian isolates obtained from different hydrobionts were categorized as $\gamma$-Proteobacteria, whereas more than a half of tropical isolates from the surface of coppercontaining plates belonged to Firmicutes. Most of 21 strains identified by phenotypic characteristics belonged to genera Bacillus and Vibrio ( Table 2 ). Genera Xanthomonas, Enterobacter, Planococcus and Serratia included one registered species each. The taxonomic position of strains 1335 and 1336 (S. oneidensis) and the strain 1355 (P. fluorescens), which were examined for capability to produce antimicrobial compounds and also were used as test cultures was determined using the results of $16 \mathrm{~S}$ rRNA gene sequencing.

Table 1. Sources and Taxonomic Position of Bacterial Strains Tested for Antimicrobial Activity.

\begin{tabular}{|c|c|c|c|}
\hline Strain No./ Gene Bank Ref. No. & Source of Isolation & Close Phylogenetic Relatives & Identity, \% \\
\hline \multicolumn{4}{|c|}{ Vietnam, Nha Trang Bay, South China Sea } \\
\hline $1242 / G U 726840^{\mathrm{a}}$ & brass & $P$ & 100 \\
\hline 1248/GU726841 & brass & P. aeruginosa & 100 \\
\hline $1263 /$ GU726843 & bronze & Alteromonas sp. & 100 \\
\hline 1341/GU726850 & brass & $B$ & 100 \\
\hline 1343/GU726852 & brass & Bacillus sp. & 99,6 \\
\hline 1344/GU726853 & brass & $P$ & 96,6 \\
\hline 1345/GU726854 & brass & $B$ & 100 \\
\hline 1346/GU726855 & brass & $B$ & 100 \\
\hline 1347/GU726856 & brass & $S$ & 100 \\
\hline 1348/GU726857 & brass & $B$ & 100 \\
\hline 1349/GU726858 & brass & $B$ & 99,8 \\
\hline 1350/GU726859 & bronze & $P$ & 97,3 \\
\hline 1351/GU726860 & bronze & Alteromonas sp. & 99.9 \\
\hline 1352/GU726861 & bronze & $B$ & 100 \\
\hline 1353/GU726862 & bronze & Alteromonas sp. & 99,9 \\
\hline 1355/GU726863 & copper & $P$ & 100 \\
\hline 1360/GU726864 & copper & Enterobactersp. & 99,5 \\
\hline 1361/GU726865 & copper & $B$ & 100 \\
\hline 1364/GU726866 & copper & Brevibacterium sp. & 99,9 \\
\hline 1365/GU726867 & copper & $B$ & 100 \\
\hline 1366/GU726868 & copper & $B$ & 99,9 \\
\hline 1367/GU726869 & brass & $B$ & 100 \\
\hline 1368/GU726870 & brass & $B$ & 100 \\
\hline 1369/GU726871 & brass & $B$ & 100 \\
\hline 1373/GU726872 & brass & $P$ & 99,9 \\
\hline
\end{tabular}




\begin{tabular}{|c|c|c|c|}
\hline 1374/GU726873 & seawater & $V$ & 99,6 \\
\hline 1382/GU726874 & aluminum & Stenotrophomonas sp & 100 \\
\hline 1389/ & aluminum & $P$ & 100 \\
\hline 1391/GU726876 & copper & Paracoccus sp. & 99,1 \\
\hline 1392/GU726877 & brass & Sphingobacterium sp. & 99,3 \\
\hline $1405 / G U 726879$ & sponge & $B$ & 99,9 \\
\hline 1441 & seawater & Staphylococcus sp. & $\mathrm{n} / \mathrm{d}^{\mathrm{b}}$ \\
\hline 1442 & seawater & Staphylococcus sp. & $\mathrm{n} / \mathrm{d}$ \\
\hline 1443 & seawater & Vibrio sp. & $\mathrm{n} / \mathrm{d}$ \\
\hline \multicolumn{4}{|c|}{$\begin{array}{l}\text { Vietnam, Nha Trang Bay, South China Sea; The East } \\
\text { China Sea }\end{array}$} \\
\hline 1444 & seawater & Ruegeria sp. & 99,9 \\
\hline 1541 & seawater & $P$ & $n / d$ \\
\hline 1542 & seawater & Vibrio sp. & $n / d$ \\
\hline \multicolumn{4}{|c|}{ Peter the Great Bay, Japan Sea, Russia } \\
\hline 915/EU579451 & trepang & $V$ & 99.8 \\
\hline 929 & trepang & $V$ & 99.1 \\
\hline 1298/GU726844 & sea urchin & $V$ & 99,9 \\
\hline 1306/GU726845 & laminaria & $V$ & 99,9 \\
\hline 1314/GU726846 & soil & $P$ & 100 \\
\hline 1333 & ouster & $P$ & 99,6 \\
\hline 1335/GU726848 & ouster & $S$ & 99,8 \\
\hline 1336/GU726849 & ouster & $S$ & 99,8 \\
\hline 1561 & seawater & $P$ & 99,5 \\
\hline 1562 & seawater & $P$ & 99,5 \\
\hline 1567 & starfish & $P$ & 99.9 \\
\hline 1569/JN679848 & starfish & $P$ & 99.9 \\
\hline 1570 & sea urchin & $P$ & 99.9 \\
\hline 1573 & starfish & $P$ & 97.3 \\
\hline 1576 & starfish & $P$ & 100 \\
\hline 1579 & bivalve & $P$ & 99.2 \\
\hline 1582 & starfish & $P$ & 99.6 \\
\hline 1589 & starfish & $P$ & 99.9 \\
\hline 1593 & starfish & $P$ & 99.9 \\
\hline 1594 & sea urchin & $P$ & 99.9 \\
\hline 1595 & trepang & $P$ & 97.1 \\
\hline 1596 & bivalve & $P$ & 99.9 \\
\hline 1597 & holothurian & $P$ & 99.9 \\
\hline 1599 & bivalve & $P$ & 99,9 \\
\hline 1601 & bivalve & $P$ & 99.8 \\
\hline 1602 & sea urchin & $P$ & 99.9 \\
\hline 1603 & sea urchin & $P$ & 99.9 \\
\hline 1604 & sea urchin & $P$ & 99.9 \\
\hline 1605 & sea urchin & $P$ & 99.9 \\
\hline
\end{tabular}

\footnotetext{
$\mathrm{a}$ The numbers of 16S rRNA gene sequences deposited in NCBI/GenBank 
Table 2. Sources and Taxonomic Position of Bacterial Test-Culture Strains .

\begin{tabular}{|c|c|c|c|}
\hline Strain No. & Source of Strain & Close Phylogenetic Relative & Identity, \% \\
\hline 1420 & Vietnam, holothurian & Bacillus & $\mathrm{n} / \mathrm{d}$ \\
\hline 1421 & Vietnam, holothurian & Bacillus & $\mathrm{n} / \mathrm{d}$ \\
\hline 1422 & Vietnam, holothurian & Bacillus & $\mathrm{n} / \mathrm{d}$ \\
\hline 1423 & Vietnam, holothurian & Vibrio & $\mathrm{n} / \mathrm{d}$ \\
\hline 1424 & Vietnam, holothurian & Vibrio & $\mathrm{n} / \mathrm{d}$ \\
\hline 1425 & Vietnam, holothurian & Vibrio & $\mathrm{n} / \mathrm{d}$ \\
\hline 1427 & Vietnam, ouster & Vibrio & $\mathrm{n} / \mathrm{d}$ \\
\hline 1430 & Vietnam, algae & Bacillus & $\mathrm{n} / \mathrm{d}$ \\
\hline 1437 & Vietnam, algae & Bacillus & $\mathrm{n} / \mathrm{d}$ \\
\hline 1438 & Vietnam, algae & Bacillus & $\mathrm{n} / \mathrm{d}$ \\
\hline 1478 & Vietnam, seawater & Bacillus & $\mathrm{n} / \mathrm{d}$ \\
\hline 1537 & Vietnam, seawater & Vibrio & $\mathrm{n} / \mathrm{d}$ \\
\hline 1543 & Vietnam, seawater & Xanthomonas & $\mathrm{n} / \mathrm{d}$ \\
\hline $1306 /$ GU726845 & Russia, laminaria & $V$ & 99.9 \\
\hline 1331 & Russia, trepang & Enterobacter sp. & $\mathrm{n} / \mathrm{d}$ \\
\hline 1333 / GU726847 & Russia, ouster & $P$ & 99.6 \\
\hline 1335 & Russia, ouster & $S$ & 99.8 \\
\hline 1336 & Russia, ouster & $S$ & 99.8 \\
\hline 1355 & Vietnam, copper & $P$ & 100 \\
\hline 1410 & Vietnam, aluminum & $S$ & 99.9 \\
\hline 1530 & Vietnam, bivalve & Vibrio sp. & $\mathrm{n} / \mathrm{d}$ \\
\hline ATCC 15034 & KMM, $\mathrm{PIBOC}^{\mathrm{a}}$ & E & $\mathrm{n} / \mathrm{d}$ \\
\hline КММ 455 & KMM, PIBOC & $C$ & $\mathrm{n} / \mathrm{d}$ \\
\hline ATCC 21027 & KMM, РIBOC & $S$ & $\mathrm{n} / \mathrm{d}$ \\
\hline B & KMM, PIBOC & $B$ & $\mathrm{n} / \mathrm{d}$ \\
\hline КММ 4 & KMM, РIBOC & $P$ & $\mathrm{n} / \mathrm{d}$ \\
\hline
\end{tabular}

$\mathrm{a}$ The strains are deposited in the Collection of Marine Microorganisms (KMM) of the Pacific Institute of Bioorganic Chemistry, Far Eastern Division, Russian Academy of Sciences, Vladivostok, Russia

\subsection{Antimicrobial Activity}

$68.97 \%$ of isolates from temperate zone and $56.76 \%$ of Vietnamese strains showed antimicrobial activity. The strains that showed the greatest activity were of tropical origin ( Table 3 ). Regarding taxonomic position of the most active strains, in both temperate and tropical zones, the undisputed leaders belonged to families Pseudomonadaceae and Pseudoalteromonadaceae ( Table 3 and Table 4 ). Among Vietnamese isolates the activity against most test cultures, besides P. aeruginosa and P. nigrifaciens, was also demonstrated by Ruegeria sp. and Bacillus spp.

All tropical strains of Alteromonas spp., Pseudomonas spp., Pseudoalteromonas spp. and Vibrio spp. tested for antimicrobial activity appeared active against two or more test cultures. 35.7\% of the genus Bacillus members showed antimicrobial activity. Two strains of Russian origin, P. putida no. 1567 and no. 1602, suppressed growth in 10 and
11 test cultures respectively (Table 4). Among pseudomonads $71.4 \%$ of strains demonstrated antimicrobial activity. A strain of $P$. piscicida suppressed growth in 10 test cultures. All Vibrio strains showed antimicrobial activity in respect to 1-4 test cultures. No antimicrobial activity was detected in the examined strains of S. oneidensis and P. maritimus and certain strains of Pseudomonas spp.

Vietnamese isolates were the most active against bacteria of genera Bacillus and Vibrio; Russian strains showed the greatest activity against Bacillus spp., S. marcescens, S. oneidensis and Vibrio spp. Tropical isolates suppressed more actively the growth of E. coli and S. aureus, whereas strains from temperate area were more active against $P$. aeruginosa. None of Russian isolates showed activity against $P$. fluorescens and $C$. albicans, whereas tropical strains of $P$. citrea and Ruegeria $s p$. suppressed the growth of $P$. fluorescens, while P. nigrifaciens and Alteromonas sp. were active against $C$. albicans. 


\begin{tabular}{|c|c|c|c|c|c|c|c|c|c|c|c|c|c|}
\hline & 1420 & 1421 & 1422 & 1423 & 1424 & 1425 & 1427 & 1430 & 1437 & 1438 & 1478 & 1537 & 1543 \\
\hline 1242 & $+^{\mathrm{a}}$ & + & + & + & - & + & + & + & + & - & + & + & + \\
\hline 1248 & + & + & + & + & + & + & + & + & - & - & + & + & + \\
\hline 1263 & - b & - & - & - & - & - & + & - & - & - & - & - & - \\
\hline 1343 & - & - & - & - & - & - & - & - & - & - & - & - & - \\
\hline 1344 & + & + & + & + & - & - & - & + & - & - & + & - & - \\
\hline 1348 & + & - & - & - & - & - & + & - & - & - & - & - & - \\
\hline 1349 & - & + & - & - & - & - & + & - & - & - & - & - & - \\
\hline 1350 & + & - & - & + & - & + & - & + & + & - & + & - & - \\
\hline 1351 & - & - & - & - & - & - & + & - & - & - & - & + & - \\
\hline 1353 & + & - & - & + & - & - & - & + & - & - & - & - & - \\
\hline 1355 & - & - & - & - & - & - & - & + & + & - & - & - & - \\
\hline 1361 & + & - & + & - & - & + & - & - & - & - & - & - & + \\
\hline 1366 & - & - & - & - & - & - & + & - & - & - & + & + & - \\
\hline 1373 & - & - & - & - & + & - & - & + & - & - & - & - & + \\
\hline 1374 & - & - & - & - & - & - & + & - & - & - & + & - & - \\
\hline 1389 & + & - & - & + & - & - & - & - & - & - & + & - & - \\
\hline 1442 & - & - & - & - & - & - & - & - & - & + & - & - & - \\
\hline 1443 & + & + & - & - & + & - & - & - & - & - & - & - & - \\
\hline 1444 & + & + & + & + & - & - & + & - & + & + & + & - & - \\
\hline 1541 & - & + & - & + & - & - & - & + & + & - & - & - & - \\
\hline \multirow[t]{2}{*}{1542} & - & - & - & - & - & - & - & + & - & + & - & - & - \\
\hline & E. coli & C. albicans & S. aureus & P. aeruginosa & B.subtilis & 1306 & 1331 & 1333 & 1335 & 1336 & 1355 & 1410 & 1530 \\
\hline 1242 & - & - & + & - & + & + & + & - & + & + & - & + & + \\
\hline 1248 & - & - & + & - & + & + & + & - & + & - & - & + & + \\
\hline 1263 & - & - & - & - & - & + & - & - & - & - & - & - & + \\
\hline 1343 & + & - & - & - & - & - & + & - & - & - & - & - & - \\
\hline 1344 & - & + & - & + & - & - & - & - & - & - & - & - & - \\
\hline 1348 & + & - & - & - & + & - & - & - & - & - & - & - & - \\
\hline 1349 & - & - & + & - & - & - & + & - & - & - & - & + & - \\
\hline 1350 & - & - & + & - & - & - & - & + & - & - & - & - & - \\
\hline 1351 & - & - & - & - & - & + & - & - & - & - & - & - & - \\
\hline 1353 & - & + & - & - & - & - & - & - & - & - & - & - & - \\
\hline 1355 & + & - & - & - & + & - & + & - & - & - & $\mathrm{n} / \mathrm{d}^{\mathrm{C}}$ & + & + \\
\hline 1361 & + & - & + & - & - & - & - & - & - & - & - & - & - \\
\hline 1366 & + & - & - & - & - & + & - & - & + & - & - & - & + \\
\hline 1373 & - & - & - & - & - & - & - & - & - & + & + & - & + \\
\hline 1374 & - & - & - & - & - & - & - & - & - & - & - & - & + \\
\hline 1389 & + & - & - & - & - & - & - & - & - & - & - & + & - \\
\hline 1442 & - & - & - & - & - & - & - & - & - & - & - & - & - \\
\hline 1443 & - & - & - & - & - & - & - & - & - & - & - & - & - \\
\hline 1444 & + & - & + & - & - & - & - & + & + & + & + & - & - \\
\hline 1541 & - & - & - & - & - & - & - & - & + & + & - & - & - \\
\hline 1542 & - & - & - & - & & - & - & - & - & & & - & - \\
\hline
\end{tabular}

\footnotetext{
${ }^{\mathrm{a}}$ Grown inhibition zone was more than $5 \mathrm{~mm}$ in diameter; ${ }^{\mathrm{b}}$ Grown inhibition zone was absent; ${ }^{\mathrm{c}} \mathrm{n} / \mathrm{d}$ - no data
} 
Table 4. Antagonistic Activity of Bacterial Isolates From Peter the Great Bay, Sea of Japan, Russia

\begin{tabular}{|c|c|c|c|c|c|c|c|c|c|c|c|c|c|}
\hline & 1420 & 1421 & 1422 & 1423 & 1424 & 1425 & 1427 & 1430 & 1437 & 1438 & 1478 & 1537 & 1543 \\
\hline 915 & - & - & - & - & - & - & + & - & - & - & - & - & - \\
\hline 929 & - & - & - & + & - & + & - & - & - & - & - & + & - \\
\hline 1298 & - & - & - & - & - & - & + & - & - & - & - & + & - \\
\hline 1306 & - & - & - & - & - & - & - & - & - & - & - & + & - \\
\hline 1314 & - & - & - & + & - & - & + & - & - & - & + & + & - \\
\hline 1561 & - & - & - & - & - & + & - & - & - & - & - & + & - \\
\hline 1562 & - & - & - & - & - & - & - & - & - & - & - & - & - \\
\hline 1567 & + & + & + & + & - & - & - & + & - & + & + & - & - \\
\hline 1569 & - & + & + & - & - & + & - & + & + & + & - & - & + \\
\hline 1570 & - & - & - & - & - & - & - & + & + & - & - & + & - \\
\hline 1576 & - & + & - & - & - & - & - & - & - & - & - & - & + \\
\hline 1579 & - & + & - & - & - & - & - & - & - & - & + & - & - \\
\hline 1582 & + & + & - & - & - & - & - & - & - & - & - & - & - \\
\hline 1594 & + & + & + & - & - & - & - & + & + & + & - & - & - \\
\hline 1596 & - & + & - & - & + & - & - & + & - & - & - & - & - \\
\hline 1597 & - & - & - & - & - & - & - & - & - & - & - & - & + \\
\hline 1602 & + & + & + & - & + & - & - & + & + & + & - & - & - \\
\hline 1603 & - & + & + & - & + & - & - & + & - & - & - & - & - \\
\hline 1604 & - & + & + & - & + & - & - & + & - & + & - & - & - \\
\hline 1605 & + & - & + & - & + & - & - & + & - & - & - & - & - \\
\hline 915 & - & - & - & - & - & - & - & - & - & - & - & - & - \\
\hline 929 & - & - & - & - & - & + & - & - & - & - & - & - & - \\
\hline 1298 & - & - & - & - & - & + & - & - & - & - & - & - & + \\
\hline 1306 & - & - & - & - & - & $\mathrm{n} / \mathrm{d}$ & - & - & - & - & - & - & - \\
\hline 1314 & + & - & + & - & - & - & + & - & + & - & - & + & + \\
\hline 1561 & - & - & - & - & + & + & + & - & + & - & - & + & + \\
\hline 1562 & - & - & + & - & + & + & + & + & - & - & - & + & - \\
\hline 1567 & - & - & - & - & + & + & - & + & - & - & - & - & - \\
\hline 1569 & - & - & - & - & - & + & + & + & - & - & - & - & - \\
\hline 1570 & - & - & - & - & - & + & - & - & + & + & - & + & + \\
\hline 1576 & - & - & - & - & - & - & - & - & - & - & - & - & - \\
\hline 1579 & - & - & - & - & - & - & - & - & - & - & - & - & - \\
\hline 1582 & - & - & - & - & - & - & - & - & - & - & - & - & - \\
\hline 1594 & - & - & - & - & - & - & - & - & + & - & - & - & - \\
\hline 1596 & - & - & - & - & - & - & - & - & + & - & - & + & - \\
\hline 1597 & - & - & - & - & - & - & - & - & - & - & - & - & - \\
\hline 1602 & - & - & - & + & - & - & - & - & + & + & - & + & - \\
\hline 1603 & - & - & - & + & - & - & - & - & + & + & - & - & - \\
\hline 1604 & - & - & - & + & - & - & - & - & + & - & - & - & - \\
\hline 1605 & - & - & - & + & - & - & - & - & - & + & - & - & - \\
\hline
\end{tabular}




\section{Acknowledgements}

The authors would like to express their deep appreciation and gratitude to the Supervisor of the research line “Tropical Material Engineering” Dr. Valery A. Karpov for invaluable support of our investigations in Vietnam and Dr. Andrey V. Smurov (A.N. Severtsov Institute of Ecology and Evolution, Russian Academy of Sciences, Moscow) for providing and identification of some tropical invertebrate animals. The type strains Escherichia coli ATCC 15034, Bacillus subtilis BKM B501, Candida albicans KMM 455, Pseudomonas aeruginosa KMM 433 u Staphylococcus aureus ATCC 21027 were kindly loaned to us by Dr. Valery V. Mikhailov (PIBOK, FEB RAS, Vladivostok).

\section{Financial Disclosure}

None declared.

\section{Funding/Support}

The project was partially supported by the Program "Integrated Regional Project of Far-Eastern Branch, Russian Academy of Sciences According the Program of the Presidium of Russian Academy of Sciences" (grants 09-I-P2301 and 09-I-P16-04).

\section{Authors' Contribution}

None declared.

\section{References}

1. Long RA, Azam F. Antagonistic interactions among marine pelagic bacteria. Appl Environ Microbiol. 2001;67(11):4975-83.

2. Fenical W, Jensen P. Marine Biotechnology. New York: Plenum Press; 1993. p. 419-57.

3. Wagner-Dobler I, Beil W, Lang S, Meiners M, Laatsch H. Integrated approach to explore the potential of marine microorganisms for the production of bioactive metabolites. Adv Biochem Eng Biotechnol. 2002;74:207-38.

4. Leifert C, Li H, Chidburee S, Hampson S, Workman S, Sigee D, et al. Antibiotic production and biocontrol activity by Bacillus subtilis CL27 and Bacillus pumilus CL45. J Appl Bacteriol.1995;78(2):97-108.

5. Akid R, Wang H, Gobata M, Smith T, Gittens J. Green coatings for industrial applications. Corrosion management. 2011;100:11-4.

6. Burgess JG, Boyd KG, Armstrong E, Jiang Z, Yan L, Berggren M, et al. The development of a marine natural product-based antifouling paint. Biofouling. 2003;19:197-205.

7. Montealegre JR, Reyes R, Pérez LM, Herrera R, Silva P, Besoain X. Selection of bioantagonistic bacteria to be used in biological control of Rhizoctonia solani in tomato. Electron J Biotechnol. 2003;6(2):115-27.

8. Podile AR, Prakash AP. Lysis and biological control of Aspergillus niger by Bacillus subtilis AF 1. Can J Microbiol. 1996;42(6):533-8.

9. Chandrika V. Incidence of Antagonistic Bacillus spp. An ecofriendly aquatic priobiotic from aquaculture pond. The Fourth Indian Fisheries Forum. 1996; p. p.147-50

10. Prado S, Montes J, Romalde JL, Barja JL. Inhibitory activity of Phaeobacter strains against aquaculture pathogenic bacteria. Int Microbiol. 2009;12(2):107-14.

11. Yebra DM, Kiil S, Dam-Johansen K. Antifouling technologypast, present and future steps towards efficient and environmentally friendly antifouling coatings. Prog Organic Coatings. 2004;50(2):75-104.
12. Beleneva I, Zhukova N. Seasonal dynamics of cell numbers and biodiversity of marine heterotrophic bacteria inhabiting invertebrates and water ecosystems of the Peter the Great Bay, Sea of Japan. Microbiology. 2009;78(3):369-75.

13. Youschimizu M, Kimura T, et al. Study on the intestinal microflora of salmonids Fish Pathol. 1976;10(2):243-259.

14. Beleneva IA, Zhukova NV, Le lan H, Ngueyen Tran DH. [Taxonomic composition of bacteria associated with cultivated mollusks Crassostrea lugubris and Perna viridis and with the water of the Gulf of Nha Trang Lagoon, Vietnam]. Mikrobiologiia. 2007;76(2):253-62.

15. Sambrook J, Fritsch E, Maniatis T. Molecular cloning: a laboratory manual. 1989.

16. Lane D. Nucleic acid techniques in bacterial systematic.. 1991; $\mathrm{p}$.

17. Saitou N, Nei M. The neighbor-joining method: a new method for reconstructing phylogenetic trees. Mol Biol Evol. 1987;4(4):406-25.

18. Kimura M. A simple method for estimating evolutionary rates of base substitutions through comparative studies of nucleotide sequences.J Mol Evol. 1980;16(2):111-20.

19. Tamura K, Peterson D, Peterson N, Stecher G, Nei M, Kumar S. MEGA5: molecular evolutionary genetics analysis using maximum likelihood, evolutionary distance, and maximum parsimony methods. Mol Biol Evol. 2011;28(10):2731-9.

20. Felsenstein J. Confidence limits on phylogenies: an approach using the bootstrap. Evolution. 1985;39(4):783-91.

21. Giovannoni S, Rappe M. Microbial ecology of the ocean. 2000; p.

22. Giovannoni S, Rappe M, Kirchman D. Microbial ecology of the ocean. 2000

23. Sharma M, Thapaliya H. Antibiotic profiling of heavy metal resistant bacterial isolates from the effluent of a garment industry in Latitpur, Nepal. Our Nature. 2009;7(1):203-6.

24. Kwon KK, Lee HS, Jung SY, Yim JH, Lee JH, Lee HK. Isolation and identification of biofilm-forming marine bacteria on glass surfaces in Dae-Ho Dike, Korea.J Microbiol Seoul. 2002;40(4):260-6.

25. Nair S, Simidu U. Distribution and significance of heterotrophic marine bacteria with antibacterial activity. Appl Environ Microbiol.1987;53(12):2957-62.

26. Shakila R, Saravanakumar R, Vyla S, Jeyasekaran G, Jasmine G. Antagonistic activity of the gut microflora isolated from farmed tiger shrimp (Penaeus monodon). Asian Fish Sci. 2006;19(3/4):247.

27. Yan L, Boyd KG, Adams DR, Burgess JG. Biofilm-specific crossspecies induction of antimicrobial compounds in bacilli. Appl Environ Microbiol. 2003;69(7):3719-27.

28. Palleroni N, Genus I, Kreig N, Holt J. Bergey's Manual of Systematic Bacteriology. 1984.

29. Rekha VA, John D, Shankar T. [Antibacterial activity of Pseudomonas fluorescens isolated from rhizosphere soill. Int J Biol Technol. 2010;1(3):10-4.

30. Romanenko LA, Tanaka N, Uchino M, Kalinovskaya NI, Mikhailov VV. Diversity and antagonistic activity of sea ice bacteria isolated from the sea of Japan. Microbes Environ. 2008;23(3):209-14.

31. Uzair B, Ahmed N, Kousar F, Edwards D. Isolation and characterization of Pseudomonas strain that inhibit growth of indigenous and clinical isolate. Internet J Microbiol. 2006;2(2).

32. Radjasa O, Martens T, Grossart H, Brinkoff T, Sabdono A, Simon M. Antagonistic activity of a marine bacterium Pseudoalteromonas luteoviolacea TAB4.2 associated with coral Acropora sp. J Biol Sci. 7(2):239-46.

33. Onishchenko O. Alteromonas-like bacteria isolated from water and invertebrate animals of the Black Sea and their antagonistic activity. Ekologiya moray. 2001;57:37-40.

34. Meziti A, Kormas KA, Pancucci-Papadopoulou MA, Thessalou-Legaki M. Bacterial phylotypes associated with the digestive tract of the sea urchin Paracentrotus lividus and the ascidian Microcosmus sp. Russ J Mar Biol. 2007;33(2):84-91.

35. Rohwer F, Seguritan V, Azam F, Knowlton N. Diversity and distribution of coral-associated bacteria. Mar Eco Prog Ser. 2002;243(1):1-10.

36. Bhattarai HD, Lee YK, Cho KH, Lee HK, hin HW. The study of an tagonistic interactions among pelagic bacteria: a promising way 
to coin environmental friendly antifouling compounds. Hydrobiologia. 2006;568(1):417-23.

37. Buchan A, Gonzalez JM, Moran MA. Overview of the marine roseobacter lineage. Appl Environ Microbiol. 2005;71(10):5665-77.

38. Porsby CH, Nielsen KF, Gram L. Phaeobacter and Ruegeria species of the Roseobacter clade colonize separate niches in a Danish Turbot (Scophthalmus maximus)-rearing farm and antagonize
Vibrio anguillarum under different growth conditions. Appl Environ Microbiol. 2008;74(23):7356-64.

39. Gana ML, Kebbouche-Gana S, Touzi A, Zorgani MA, Pauss A, Lounici $\mathrm{H}$, et al. Antagonistic activity of Bacillus sp. obtained from an Algerian oilfield and chemical biocide THPS against sulfatereducing bacteria consortium inducing corrosion in the oil industry.J Industrial microbiol Biotechnol. 2011;38(3):391-404. 